\title{
BULLYING DI SEKOLAH : KURANGNYA EMPATI PELAKU BUILYING DAN PENCEGAHAN
}

\author{
Bety Agustina Rahayu*, Iman Permana \\ Magister Keperawatan Universitas Muhammadiyah Yogyakarta \\ *betyagustinarahayu@yahoo.co.id
}

\begin{abstract}
ABSTRAK
Penelitian terkait kasus bullying pada anak usia sekolah dasar masih terbatas. Tujuan dilakukan penelitian ini untuk menganalisis faktor-faktor perilaku bullying di Sekolah Dasar Negeri Pungkuran Pleret Bantul. Penelitian ini menggunakan desain studi kasus. Teknik total sampling dipilih dalam penelitian ini. Responden adalah 102 siswa dan seorang kepala sekolah.Wawancara penelitian dilakukan pada 10 partisipan siswa yang diambil dengan purposive sampling.Instrument yang digunakan termasuk kuesioner kebiasaan siswa di sekolah, pedoman wawancara, telepon dan lembar observasi. Tingkat perilaku bullying mayoritas dalam kategori bullying sedang dilakukan 62,31\% siswa laki-laki . Jenis bullying verbal kategori sedang banyak ditemukan pada 42,16\% siswa laki-laki. Sebanyak 39,22\% siswa laki-laki cenderung melakukan bullying fisik tingkat rendah. Bullying relasional kategori sedang dilakukan oleh 48,04 \% siswa laki-laki. Bullying yang terjadi disekolah terjadi karena kurangnya empati pelaku bullying dan pencegahan yang dilakukan oleh sekolah. Pemicu bullying dikalangan siswa adalah ketidakpedulian. Ketidaktersediaan standar operasional prosedur dan guru konseling menjadi faktor rantai bullying yang berkelanjutan.
\end{abstract}

Kata kunci: perilaku, bullying; sekolah dasar

\section{LACK OF BULLIES EMPATHY AND PREVENTION AT SCHOOL}

\begin{abstract}
Research related cases of bullying in elementary school-age children has limited. The purpose of this study was to analyze the factors of bullying behavior at Pungkuran Pleret Public Elementary School in Bantul. This study uses a case study design. We applied a total sampling technique. All respondents were 102 students and a principal. We also conducted interviews with ten students obtained by purposive sampling. The instruments used included questionnaires for student habits at school, interview guidelines, telephones and observation sheets. The level of bullying behaviour in the majority in the category of bullying is being done by $62.31 \%$ male students. The type of verbal bullying category is mostly found in $42.16 \%$ male students. Almost $39.22 \%$ of male students are likely to conduct low physical bullying, and most relational bullying found are done by 48,04\% these male students. Bullying that occurs in schools occurs because of a lack of empathy perpetrators of bullying and prevention carried out by the school. The trigger for bullying among students is indifference. Moreover, the unavailability of standard operational procedures and counselling teachers are found becoming the factors in the continued chain of bullying.
\end{abstract}

Keywords: behavior, bullying, elementary school

\section{PENDAHULUAN}

Bullying yang terjadi di lingkungan sekolah telah menjadi masalah global. Tidak sedikit orang tua dan sekolah berpandangan bahwa bullying hanya terjadi pada siswa dengan jenjang SMP dan SMA, padahal faktanya banyak pula terjadi pada anak sejak rentang usia 3 sampai 12 tahun. Pada usia inilah kasus bullying kurang mendapatkan perhatian karena dianggap sebagai hal yang wajar (Sari and Azwar, 2017).
Data dari National Center for Educational Statistic (2016) lebih dari satu dari setiap lima $(20,8 \%)$ siswa melaporkan ditindas. Data dari International Center for Research on Women (ICRW) melaporkan bahwa $84 \%$ anak Indonesia mengalami kekerasan di lingkungan sekolah. Data ini menunjukkan angka yang sangat memprihatinkan, mengingat sekolah adalah tempat menimba ilmu sehingga dapat dikatakan kondisi ini sangat mencoreng dunia 
pendidikan. Data yang didapatkan dari Komisi Perlindungan Anak Indonesia (KPAI) di tahun 2018, ditemukan kasus dibidang pendidikan sebanyak 161 kasus, $36(22,4 \%)$ merupakan kasus dengan anak korban kekerasan dan bullying, sedangkan kasus anak pelaku kekerasan dan bullying sebanyak $41(25,5 \%)$ (Eliasa, 2017).

UNICEF mengatakan $21 \%$ kasus perundungan terjadi pada anak di Daerah Istimewa Yogyakarta (Rukmantara, 2019). Data dari DP3AP2KB Sleman mencatat ada 179 kasus perundungan atau bullying ditingkat usia anak hingga remaja cukup tinggi di tahun 2018 (Linda, 2019). Seriusnya permasalahan bullying bukan hanya serius bagi pihak-pihak yang menjadi korban, tetapi merupakan permasalahan besar bagi semua.Korban bullying bisa berubah menjadi pelaku bullying dikemudian hari.Bullying merupakan suatu tindakan yang lebih menunjukkan perilaku yang agresif dan manipulative, yang dapat dilakukan oleh satu orang atau lebih yang ditunjukkan kepada orang lain, seringnya berisi kekerasan dan menunjukkan adanya ketidakseimbangan kekuatan anatara korban dan pelaku bullying (Novitasari, 2017).

Weber (2014) menyebutkan bahwa ada empat faktor yang dapat menyebabkan seseorang berperilaku bullying antara lain faktor individu, keluarga, lingkungan, dan teman sebaya (Zakiyah, Humaedi and Santoso, 2017). Siswa sekolah dasar berada pada usia sekolah antara usia 6 sampai 12 tahun. Diusia sekolah ini disebut sebagai masa intelektual, dimana anak akan mulai berpikir secara konkrit dan rasional untuk menghadapi tantangan baru. Periode anak usia sekolah merupakan tahap dimana anak dianggap mulai bertanggungjawab pada perilaku yang dilakukan sendiri dan meniru dari apa yang dilihat (Yusuf, 2011).

Dampak luar biasa dari bullying akan terjadi pada pelaku dan korban. Pelaku akan memiliki watak keras, dan merasa memiliki kekuasaan, korban bullying akan merasa cemas, dapat meningkat kearah depresi yang dapat berakhir dengan bunuh diri. Korban bullyingakan berkaca dari tindakan apa yang pernah diterima, tindakan ekstrim lainnya korban akan melakukan balas dendam pada pelaku bullying yang tentu saja dalam bentuk yang lebih ekstrim. Korban bullying akan berubah kondisi menjadi pelaku bullying (Kusuma, 2016).
Bullying telah diakui sebagai pemicu dari masalah kesehatan bagi anak sekolah terutama anak pada jenjang sekolah dasar, karena mereka berhubungan dengan berbagai masalah penyesuaian termasuk kesehatan mental yang buruk dan perilaku kekerasan (Kusuma, 2016). Bullying berpeluang besar untuk ditiru, siswa yang melakukan bullying bisa terjadi setelah mereka sendiri pernah mendapatkan perlakuan bullying misalnya pernah disakiti oleh orang yang lebih kuat, misalnya orang tua, kakak, atau teman sebaya yang lebih dominan (Fatmawati, 2016).

SDN Pungkuran Pleret Bantul merupakan salah satu sekolah dasar yang terletak di Daerah Istimewa Yogyakarta.Data tentang bullying pada anak sekolah dasar di wilayah Bantul belum banyak terpantau.Penelitian tentang bullying pada siswa sekolah dasar juga belum ditemukan. Penelitian ini mengambil tempat di SDN Pungkuran Pleret Bantul Yogyakarta karena dari hasil studi pendahuluan yang telah dilakukan pada tanggal 13 Nopember 2018 terdapat beberapa kasus bullying yang kurang mendapatkan perhatian. Hasil observasi dalam studi pendahuluan terdapat siswa yang bertengkar dengan mengolok-olok temannya dengan panggilan nama orang tua. Hasil wawancara dengan beberapa anak kelas 4 yang sedang bermain saat jam istirahat didapatkan data mereka mengatakan ada teman yang mengejek teman lain hingga menangis, pernah juga ada anak yang meludahi temannya karena diejek. Satu dari lima siswa yang diwawancarai mengatakan pernah menangis dan pulang saat diejek temannya.

Hasil wawancara dengan guru, didapatkan data bahwa banyak kasus bullying di SDN Pungkuran Pleret Bantul. Guru mengatakan contoh kasus bullying yang terjadi seperti mengejek, memukul, mendiamkan salah satu teman yang membuat korban menangis sering terjadi. Kepala sekolah mengatakan banyak kasus bullying yang mengakibatkan siswa tidak mau berangkat sekolah, orang tua melaporkan anaknya tidak mau sekolah karena dimusuhi temannya, dan ada juga orang tua yang datang dan memintakan ijin anaknya untuk pindah sekolah dengan alasan dinakali temannya.

Bullying yang dilakukan secara terus menerus paling sedikit 6 bulan menunjukkan salah satu ciri dari conduct disordes, namun anak hanya 
akan dikatakan conduct disorder jika memenuhi beberapa ciri lain yang disebutkan dalam DSM IV. Perilaku bullying ini sering tumpang tindih dengan beberapa jenis abnormalitas pada anak. Anak-anak masih dikatakan normal jika melakukan bullying dalam frekuensi yang rendah, namun jika perilaku ini dilakukan secara terus menerus harus diwaspadai akan adanya indikasi keabnormalitasan pada anak tersebut. Berdasarkan data-data yang ada peneliti tertarik menganalisis faktor-faktor yang mempengaruhi perilaku bullying yang terjadi di SDN Pungkuran Pleret Bantul.

Bullying yang terjadi di lingkungan sekolah telah menjadi masalah global. Tidak sedikit orang tua dan sekolah berpandangan bahwa bullying hanya terjadi pada siswa dengan jenjang SMP dan SMA, padahal faktanya banyak pula terjadi pada anak sejak rentang usia 3 sampai 12 tahun. Pada usia inilah kasus bullying kurang mendapatkan perhatian karena dianggap sebagai hal yang wajar (Sari and Azwar, 2017).

Data dari National Center for Educational Statistic (2016) lebih dari satu dari setiap lima $(20,8 \%)$ siswa melaporkan ditindas. Data dari International Center for Research on Women (ICRW) melaporkan bahwa $84 \%$ anak Indonesia mengalami kekerasan di lingkungan sekolah. Data ini menunjukkan angka yang sangat memprihatinkan, mengingat sekolah adalah tempat menimba ilmu sehingga dapat dikatakan kondisi ini sangat mencoreng dunia pendidikan. Data yang didapatkan dari Komisi Perlindungan Anak Indonesia (KPAI) di tahun 2018, ditemukan kasus dibidang pendidikan sebanyak 161 kasus, $36(22,4 \%)$ merupakan kasus dengan anak korban kekerasan dan bullying, sedangkan kasus anak pelaku kekerasan dan bullying sebanyak $41(25,5 \%)$ (Eliasa, 2017).

UNICEF mengatakan $21 \%$ kasus perundungan terjadi pada anak di Daerah Istimewa Yogyakarta (Rukmantara, 2019). Data dari DP3AP2KB Sleman mencatat ada 179 kasus perundungan atau bullying ditingkat usia anak hingga remaja cukup tinggi di tahun 2018 (Linda, 2019). Seriusnya permasalahan bullying bukan hanya serius bagi pihak-pihak yang menjadi korban, tetapi merupakan permasalahan besar bagi semua.Korban bullying bisa berubah menjadi pelaku bullying dikemudian hari.Bullying merupakan suatu tindakan yang lebih menunjukkan perilaku yang agresif dan manipulative, yang dapat dilakukan oleh satu orang atau lebih yang ditunjukkan kepada orang lain, seringnya berisi kekerasan dan menunjukkan adanya ketidakseimbangan kekuatan anatara korban dan pelaku bullying (Novitasari, 2017).

Weber (2014) menyebutkan bahwa ada empat faktor yang dapat menyebabkan seseorang berperilaku bullying antara lain faktor individu, keluarga, lingkungan, dan teman sebaya (Zakiyah, Humaedi and Santoso, 2017). Siswa sekolah dasar berada pada usia sekolah antara usia 6 sampai 12 tahun. Diusia sekolah ini disebut sebagai masa intelektual, dimana anak akan mulai berpikir secara konkrit dan rasional untuk menghadapi tantangan baru. Periode anak usia sekolah merupakan tahap dimana anak dianggap mulai bertanggungjawab pada perilaku yang dilakukan sendiri dan meniru dari apa yang dilihat (Yusuf, 2011).

Dampak luar biasa dari bullying akan terjadi pada pelaku dan korban. Pelaku akan memiliki watak keras, dan merasa memiliki kekuasaan, korban bullying akan merasa cemas, dapat meningkat kearah depresi yang dapat berakhir dengan bunuh diri. Korban bullyingakan berkaca dari tindakan apa yang pernah diterima, tindakan ekstrim lainnya korban akan melakukan balas dendam pada pelaku bullying yang tentu saja dalam bentuk yang lebih ekstrim. Korban bullying akan berubah kondisi menjadi pelaku bullying (Kusuma, 2016).

Bullying telah diakui sebagai pemicu dari masalah kesehatan bagi anak sekolah terutama anak pada jenjang sekolah dasar, karena mereka berhubungan dengan berbagai masalah penyesuaian termasuk kesehatan mental yang buruk dan perilaku kekerasan (Kusuma, 2016). Bullying berpeluang besar untuk ditiru, siswa yang melakukan bullying bisa terjadi setelah mereka sendiri pernah mendapatkan perlakuan bullying misalnya pernah disakiti oleh orang yang lebih kuat, misalnya orang tua, kakak, atau teman sebaya yang lebih dominan (Fatmawati, 2016).

SDN Pungkuran Pleret Bantul merupakan salah satu sekolah dasar yang terletak di Daerah Istimewa Yogyakarta.Data tentang bullying pada anak sekolah dasar di wilayah Bantul belum banyak terpantau.Penelitian tentang bullying pada siswa sekolah dasar juga 
belum ditemukan. Penelitian ini mengambil tempat di SDN Pungkuran Pleret Bantul Yogyakarta karena dari hasil studi pendahuluan yang telah dilakukan pada tanggal 13 Nopember 2018 terdapat beberapa kasus bullying yang kurang mendapatkan perhatian. Hasil observasi dalam studi pendahuluan terdapat siswa yang bertengkar dengan mengolok-olok temannya dengan panggilan nama orang tua. Hasil wawancara dengan beberapa anak kelas 4 yang sedang bermain saat jam istirahat didapatkan data mereka mengatakan ada teman yang mengejek teman lain hingga menangis, pernah juga ada anak yang meludahi temannya karena diejek. Satu dari lima siswa yang diwawancarai mengatakan pernah menangis dan pulang saat diejek temannya.

Hasil wawancara dengan guru, didapatkan data bahwa banyak kasus bullying di SDN Pungkuran Pleret Bantul. Guru mengatakan contoh kasus bullying yang terjadi seperti mengejek, memukul, mendiamkan salah satu teman yang membuat korban menangis sering terjadi. Kepala sekolah mengatakan banyak kasus bullying yang mengakibatkan siswa tidak mau berangkat sekolah, orang tua melaporkan anaknya tidak mau sekolah karena dimusuhi temannya, dan ada juga orang tua yang datang dan memintakan ijin anaknya untuk pindah sekolah dengan alasan dinakali temannya.

Bullying yang dilakukan secara terus menerus paling sedikit 6 bulan menunjukkan salah satu ciri dari conduct disordes, namun anak hanya akan dikatakan conduct disorder jika memenuhi beberapa ciri lain yang disebutkan dalam DSM IV. Perilaku bullying ini sering tumpang tindih dengan beberapa jenis abnormalitas pada anak. Anak-anak masih dikatakan normal jika melakukan bullying dalam frekuensi yang rendah, namun jika perilaku ini dilakukan secara terus menerus harus diwaspadai akan adanya indikasi keabnormalitasan pada anak tersebut. Berdasarkan data-data yang ada peneliti tertarik menganalisis faktor-faktor yang mempengaruhi perilaku bullying yang terjadi di SDN Pungkuran Pleret Bantul.

\section{METODE}

Penelitian ini menggunakan desain studi kasus. Teknik total sampling dipilih dalam penelitian ini. Responden adalah 102 siswa dan seorang kepala sekolah.Wawancara penelitian dilakukan pada 10 partisipan siswa yang diambil dengan purposive sampling.Instrument yang digunakan termasuk kuesioner kebiasaan siswa di sekolah, pedoman wawancara, telepon dan lembar observasi.

Uji credibility dengan triangulasi teknik dan sumber. Teknik yang digunakan antara lain observasi, wawancara, dokumentasi dan kuesioner kebiasaan anak di sekolah. Hasil perilaku bullying dari kuesioner dilakukan koding dan diolah dengan SPSS IMB 20 dengan metode deskriptif untuk menganalisanya.Peneliti mengelompokkan bullying berdasarkan jenisnya yaitu verbal, fisik dan relasional. Dan dilakukan pengaktegorisasian berdasarkan tingkatkan bullying yaitu tinggi sedang dan rendah.Teknik analisis menggunakan analisis Miles dan Huberman.

Peneliti melakukan koleksi data, pengumpulan hasil deskripsi fenomena melalui pernyataan partisipan yang dilakukan melalui wawancara kuesioner, dan rekaman. Hasil koleksi data dituliskan dalam bentuk transkrip untuk dideskripsikan gambaran dari konsep penelitian.Kemudian dilakukan proses membaca transkrip hasil deskripsi fenomena yang telah disampaikan oleh semua partisipan. Selanjutnya dilakukan pengutipan pernyataanpernyataan yang bermakna dari partisipan yang disebut dengan reduksi data. Reduksi data diambil dari pernyataan-pernyataan yang sesuai dengan tujuan khusus penelitian, dengan cara memberikan penanda sebagai kata kunci sehingga menbentuk kategori dan tema. Selanjutnya setelah semua informasi terkumpul kemudian dilakukan penyusunan hasil yang merupakan penyajian data secara teks naratif yang memudahkan untuk memahami apa yang terjadi. Dalam penelitian ini akan dibentuk skema untuk memudahkan dalam pembacaan dan pemahaman hasil

\section{HASIL}

Hasil penelitian terkait karakteristik disajikan pada tabel berikut: 
Tabel 1.

Karakteristik populasi responden $(n=102)$

\begin{tabular}{llcc}
\hline \multicolumn{1}{c}{ Karakteristik } & \multicolumn{1}{c}{ Kategori } & $\mathrm{f}$ & $\%$ \\
\hline Jenis Kelamin & Laki-Laki & 58 & 56,9 \\
& Perempuan & 44 & 43,1 \\
\hline Umur & $8-10$ & 55 & 53,92 \\
& $11-13$ & 45 & 44,12 \\
& $14-16$ & 2 & 1,96 \\
\hline
\end{tabular}

Mayoritas siswa yang terlibat dalam penelitian ini adalah laki-laki yang berada pada rentang umur 8-10 tahun, dengan tingkat perilaku bullying pada kategori bullying sedang.Partisipan penelitian yang diwawancarai adalah siswa kelas 4, 5 dan 6 dengan tiga peringkat bullying tertinggi dikelasnya.Pemilihan partisipan ini berdasarkan penilaian kuesioner yang telah disebar dan diisi oleh siswa pada tahap sebelumnya. Peneliti melakukan wawancara pada 10 siswa yang terdiri dari, 3 siswa kelas 4, 4 siswa kelas 5, dan 3 siswa dari kelas 6 . Berikut adalah karakteristik dari masingmasing partisipan :

Tabel 2.

Gambaran Partisipan (n=10)

\begin{tabular}{|c|c|c|c|}
\hline Inisial & Usia & Kelas & Tingkat Bullying \\
\hline P1 & 10 & 4 & Sedang \\
\hline P2 & 9 & 4 & Sedang \\
\hline P3 & 9 & 4 & Sedang \\
\hline P4 & 10 & 5 & Sedang \\
\hline P5 & 12 & 5 & Sedang \\
\hline P6 & 10 & 5 & Sedang \\
\hline P7 & 10 & 5 & Sedang \\
\hline P8 & 11 & 6 & Sedang \\
\hline P9 & 15 & 6 & Sedang \\
\hline P10 & 11 & 6 & Sedang \\
\hline
\end{tabular}

Sepuluh siswa yang terpilih dalam wawancara terdiri dari 8 siswa laki-laki dan 2 siswa perempuan.siswa diwawancarai seputar pertanyaan alasan siswa melakukan bullying di sekolah.

\section{Perilaku Bullying}

Hasil dari olah data terdapat $33 \quad(32,35 \%)$ siswa yang melakukan bullying dengan kategori rendah, dan $69(67,65 \%)$ siswa yang melakukan bullying kategori sedang. Perilaku bullyingmayoritas dalam kategori sedang yang banyak dilakukan oleh siswa laki-laki sebanyak 43 siswa $(62,30 \%)$.Pengukuran dan penilaian yang telah dilakukan menunjukkan hasil bullying verbal sedang. Bullying fisik kategori rendah dan bullying relasional kategorisedang. Berikut anlisa dari setiap jenis bullying :

\section{Bullying verbal}

Mayoritas bullying verbal dalam kategori bullying tingkat sedang sebanyak 72 siswa. Siswa laki-laki banyak melakukan bullying verbal tingkat sedang dengan jumlah 43 siswa $(59,70 \%)$. Hasil observasi yang dilakukan pada
10 partisipan semuanya terdata melakukan bullying verbal. Beberapa tindakan siswa yang termasuk dalam bullying verbal adalah mempermalukan teman, memberikan julukan nama, mengganggu dan membentak dengan nada kasar. Berikut pernyataan siswa terkait contoh bullyingverbal :

"Yo ngelok-ngelok ke ngono...Nyeluk bagas gasingan" (P1)

tahu, akukan pindahan dari kelas 2 itu dipanggilnya tron tron trus aku ya ikut-ikutan" (P3)

"Ya iseng ae, nyeluk jenenge bapak e, ngelokke"...... "Nyeluk nggo jenenge bapak e, tapi tegar yang mule dulu" (P5)

\section{Bullying fisik}

Bullying fisik yang dilakukan siswa mayoritas termasuk pada kategori bullying tingkat rendah sebanyak 76 siswa dan mayoritas dilakukan oleh siswa laki-laki sebanyak 40 siswa $(52,60 \%)$. Beberapa bentuk bullying fisik yang 
terdata dari hasil obervasi dan wawancara dengan 10 partisipanantara lain berkelahi, mendorong badan, memukul, mencubit, melempar barang, mengejar, meletakkan sampah di atas kepala teman, moles, menjambak, dan menyembunyikan barang. Hasil wawancara yang mendukung adanya tindakanbullying fisik yang dilakukan antara lain sebagai berikut :

"Ngelok-ngelok ke... pernah nyok-nyok geludan...nendang, ngoyak, ngantem” (P1)

"Tak balas lebih banter... kalau ngece bales ngece nek mukul tak bales mukul lebih banter" (P9)

“Moles...bar moles panas” (P9) (P8)

\section{Bullying relasional}

Hasil pengukuran dan penilaian didapatkan hasil perilaku bullying relasional siswa di SDN Pungkuran Pleret mayoritas dalam kategori bullying relasional sedang sebanyak 86 siswa $(84,31 \%)$, dan 16 siswa $(15,69 \%)$ dalam kategori bullying relasional rendah. Dari 10 partisipan yang mengikuti penelitian tahap kedua didapatkan hasil observasi 2 siswa menampilkan bahasa tubuh yang negative seperti mengacungkan kepalan tangan kepada temannya, mendiamkan teman, dan 3 siswa menghindari korban (teman).Berikut beberapa partisipan yang pernah melakukan bullyingrelasional :

"Aku ya pernah bilang gitu... Ojo dolanan mbi kae... Pas nakali aku ben ran de konco toooo" (P9)

\section{"Mal ojo dolanan mbi kae" (P8)}

\section{Kurangnya Empati Pelaku Bullying}

Kurangnya empati yang dimiliki siswa mejadi faktor penyebab bullying terjadi di sekolah. Kurangya empati ini ditunjukkan dari beberapa hasil wawancara yang menyatakan sekedar iseng, "guyon", membuat bahan candaan, "njaraki", bermain-main, "pengen ngejek ae", dan ikut-ikutan.Adanya perasaan kosong dan tidak adanya kegiatan membuat siswa melakukan bullying.Rasa kekecewaan juga muncul menjadi faktor penyebab bullying. Pelaku merasa sebel, tidak suka dengan korban,adanya teman merusak barang, diejek duluan, dan balas dendam merupakan alasan pelaku melakukan bullying .
Kurangnya empati juga muncul pada pernyataan siswa yang menganngap "biasa wae" setelah melakukan bullying dan saat melihat kejadian bullying. Adanya perasaan lebih berkuasa yang menganggap sebagai bos, ketua kelas, wakil ketua kelas juga muncul dari hasil wawancara.Alasan tidak takut dengan ibu guru dan orangtua sehingga siswa tetap melakukan bullying dengan anggapan mengejek karena bercanda. Terdapat juga alasan untuk pertahanan diri juga muncul sehingga siswa melakukan bullying. Siswa mengejek dahulu agar tidak diejek.

\section{Kurangnya Pencegahan Sekolah}

Kurangnya pencegahan sekolah terhadap tindakan bullying menunjukkan sikap apatis lingkungan.Hasil wawancara dengan kepala sekolah yang menganggap bullying atau mengejek pada siswanya merupakan hal yang wajar untuk anakanak.SDN Pungkuran Pleret tidak memiliki data terkait pelaporan kasus bullying ataupun data pelanggaran siswa selama di sekolah, tidak memiliki guru bimbingan konseling maupun ruangan konseling, jika ada kasus ketidak disiplinan siswa diatasi atau diarahkan kepada guru olahraga untuk dinasehati dan didisiplinkan.Guru olahraga belum memiliki sertifikat konseling dan belum pernah mengikuti pelatihan konseling. Kepala sekolah tidak bisa terlalu keras pada siswa, karena banyak siswa dan orang tua yang lebih agresive seperti kasus ditelevisi.Kondisi ini diperkuat dengan pernyataan dari kepala sekolah yang menyatakan :

"Ya gimana mbak, ....guru-guru juga sangat berhati-hati menghadapi siswanya. Pernah ada juga mbak disini guru yang njewer saking kebangetannya gitu, besoknya orangtua nya datang kok mbak, melapor ke saya, jadi sekarang guru ya harus menahan diri" (P11)

"Orangtua siswa disini tu memang terlalu susah, beda dengan orangtua jaman dulu paham tujuannya belajar ya semua diserahkan kepada sekolah. Sekarang malah banyak orangtua yang mengintervensi sekolah" ... kemarin itu orangtua datang minta anak atas nama A mohon ditegur karena anak saya tidak mau sekolah karena dinakali. Tapi ya saya klarifikasi. Malah bilang kalau sampai anak A masih sekolah disini anaknya mau dipindah. Tapi ya sekolah tidak bisa mengintervensi mengeluarkan anak dari sekolah.Kan tugas sekolah mendidik, ya kita tetep berusaha 
mendidik mengawasi mereka selama disekolah. (P11)

\section{PEMBAHASAN}

\section{Kurangnya Empati Pelaku Bullying}

Empati menurut KBBI daring (2019) merupakan keadaan mental yang membuat seseorang merasa dirinya dalam perasaan atau pikiran yang sama dengan orang lain.Siswa melakukan bullying dengan alasan iseng.Iseng menurut KBBI daring (2019) merupakan adanya perasaan menganggur, tidak ada yang perlu segera dikerjakan, sehingga melakukan sesuatu agar tidak menganggur dengan alasan main-main atau tidak bersungguh-sungguh.

Alasan "Guyon" juga menjadi munculnya bullying di sekolah. "Guyon" menurut KBBI daring (2019) guyon berarti bergurau.Alasan berikutnya adalah "njarak i" berasal dari bahasa jawa yang artinya menjahili, jika dilihat dari KBBI daring (2019) diartikan sebagai membodohi.Dolanan merupakan bahasa jawa dari kata bermain-main, dalam KBBI daring (2019) diartikan sebagai melakukan suatu tidak dengan sungguh-sungguh dengan tujuan bersenang-senang.

"pengen ngejek ae" disampaikan siswa sebagai alasan bullying, jika diartikan dalam bahasa Indonesia diartikan sebagai keingingan mengejek saja. Terakhir adalah kode ikutikutan, siswa melakukan bullying karena adanya contoh.Ketujuh kode ini memiliki kesamaan maksud yaitu melakukan bullyingtanpa adanya tujuan yang bermanfaat.Semua ditujukan untuk mengisi kekosongan waktu saja.

Rasa kekecewaan yang menjadi penyebab bullying seperti sebel, tidak suka dengan korban, adanya teman merusak barang, diejek duluan, dan balas dendam merupakan alasan pelaku melakukan bullying. Kurangnya empati juga muncul pada pernyataan siswa yang menganngap "biasa wae" setelah melakukan bullying dan saat melihat kejadian bullying. Adanya perasaan lebih berkuasa yang menganggap sebagai bos, ketua kelas, wakil ketua kelas juga muncul dari hasil wawancara.Alasan tidak takut dengan ibu guru dan orangtua sehingga siswa tetap melakukan bullying dengan anggapan mengejek karena bercanda.Terdapat juga alasan untuk pertahanan diri juga muncul sehingga siswa melakukan bullying.Siswa mengejek dahulu agar tidak diejek.
Kurangnya empati menjadi faktor yang banyak muncul sebagai alasan melakukan bullying.BaronCohen (dalam Fikrie, 2016) mendefinisikan empati merupakan kemampuan untuk mengidentifikasi apa yang sedang difikirkan atau dirasakan oleh orang lain dalam rangka untuk merespon pikiran dan perasaan mereka dengan sikap yang tepat. Empati dipengaruhi oleh kapasitas pengamat, tinggi rendahnya empati seseorang juga dipengaruhi oleh kemampuan intelektual (Taufik, 2012).Seseorang yang memiliki empati yang rendah akan kurang mampu merespon tekanan dan rasa ketidaknyamanan dari orang lain yang menjadi korban, mereka tidak mampu menghubungkan perilaku antisosial yang dia lakukan dengan dengan reaksi emosional orang lain (Jolliefe\&Farrington, 2006).

Penelitian ini responden adalah siswa sekolah dasar. Empati akan berkembang sesuai dengan tahapan usia (Volbrecht Lemery et all, 2007 dalam Fidrayani, 20015). Pada usia anak-anak empati masih ditunjukkan lebih kepada orang tuanya dibandingkan orang lain (Van Der Mark et all, 2002 dalam Fidrayani, 2015). Perkembangan empati dimulai pada saat anak-anak lahir sampai dewasa. Pada usia sebelum memasuki sekolah, empati pada anak dimulai dengan respon mereka terhadap tekanan orang lain, kemudian keyakinan benar dan salah. Pada usia sekolah dasar, anak mulai memahami pandangan orang lain. Olehnya itu, perlu dikembangkan empati sebagai salah satu upaya pembentukan karakter baik sejak usia dini. Beberapa strategi dan model pembelajaran dapat diintegrasikan untuk memfasilistasi perkembangan empati, bahkan dapat dilakukan melalui integrasi mata pelajaran.

Kemampuan untuk berempati meningkatkan perilaku positif terhadap orang lain dan memfasilitasi hubungan dan interaksi sosial. Empati dapat meningkatkan kepatuhan anak terhadap aturan, dan juga meningkatkan mekanisme perilaku menolong, selain itu empati juga memainkan peranan penting terhadap kompetensi sosial seseorang yang memiliki hubungan sosial yang bermakna.Perkembangan empati yang tidak optimal mengakibatkan autisme dan psikopat. Pengembangan empati perlu diberikan pihak sekolah agar hal-hal yang tidak diinginkan tidak terjadi. Salah satunya rantai bullying akan terhenti dengan adanya program pengembangan empati. 


\section{Kurangnya Pencegahan Sekolah}

Kurangnya pencegahan sekolah terbukti dari hasil wawancara dengan kepala sekolah dan siswa yang membentuk kategori dalam penelitian ini yaitu adanya sikap apatis lingkungan.Sikap apatis lingkungan terwujud dalam ketidaktersediaan guru bimbingan konseling dan standar operasional prosedur (SOP) sekolah terkait dengan bullying.Hasil wawancara denga kepala sekolah yang menganggap mengejek itu hal yang wajar pad anak-anak. Kondisi inilah yang menyebabkan rantaibullying tetap ada di SDN Pungkuran Pleret Bantul.

Standar operasional prosedur (SOP) merupakan dokumen yang berkaitan dengan prosedur yang dilakukan secara kronologis untuk menyelesaikan suatu masalah dengan tujuan memperoleh hasil yang efektif. SOP bullying penting untuk mengingat kejadian bullying yang banyak terjadi di SDN Pungkuran Pleret dengan kategori tingkat bullying sedang. Hal ini sejalan dengan (Sari and Azwar, 2017) yang menyatakan bullying yang tidak mendapatkan perhatian dari lingkungan maka siswa akan mempersepsikan bullying bukan merupakan hal yang menyebabkan hukuman dan malah membuat pelaku mendapatkan dukungan akan hal tersebut. Adapun hukuman yang tidak membuat jera juga akan membuat siswa mengulangi bullying. Kebal dalam KBBI daring (2019) diartikan sebagai tidak mempan.Siswa yang sudah sering melakukan bullying dengan tidak mendapatkan sanksi yang tegas membuat siswa tidak mempan dengan hukuman yang diberikan.Hal ini membuat siswa menjadi kebal dan rantai bullying tetap ada.

Sekolah perlu mempunyai guru dan ruang konseling untuk mengatur kedisiplinan siswa, dengan adanya unit kedisipilnan harapannya menjadi langkah siswa untuk patuh pada tata tertib dan memiliki rasa menghargai antar siswa, guru dan seluruh masyarakat sekolah.Kondisi bullying di sekolah yang tidak segera diatasi dapat mengakibatkan trauma, ketakutan, kecemasan, depresi bahkan dapat menyebabkan kematian (Kusuma, 2016). Perilaku bullying pada anak usia 5-12 tahun berdampak negative bagi pelaku, anak-anak yang suka melakukan bullying memiliki kemungkinan untuk terlibat dalam aksi kekerasan atau beresiko lainnya ketika dewasa. Anak-anak memiliki resiko lebih tinggi untuk menjadi pecandu narkoba dan alcohol, terlibat tawuran, tindakan criminal, dan menyimpan potensi untuk melakukan kekerasan dalam rumah tangga kepada pasangan dan anaknya ketika sudah berkeluarga (Dewi, 2016).

Terkait kurangnya empati yang dimiliki siswa sehingga bullying terjadi, sekolah dapat memberikan materi terkait pengembangan empati siswanya. Hal ini diperkuat dengan hasil penelitian dari Anami (2018) yang memaparkan data dan upaya-upaya guru PAI dalam membangun sikap empati siswa merupakan upaya agar menjadi karakter social pada diri siswa menjadi seseorang menghargai, menghormati perbedaan satu sama lain baik sifat, kondisi fisik, agama, jabatan dan perbedaan potensi-potensi yang dimiliki. Hasil menunjukkan siswa yang berkualitas tidak hanya dari sisi religious, cerdas dari sisi kognitif namun memiliki social yang tinggi yang dapat diterapkan dalam kehidupan seharihari sehingga menjadi manusia yang berakhlak mulia, mampu menjaga hubungan dengan Allah SWT (Hablum MinnaAllah), dan hubungan antara manusia dengan manusia lain (Hablum MinanNaas)menjadikan mereka (siswa) sebagai manusia yang seutuhnya.Adapun Upaya yang dilakukan Guru PAI dalam membangun Empati siswadalam proses pembelajaran PAI di SD Negeri 01 Klodranmelalui metode-metode pembelajaran.

Beberapa metode digunkaan dalam penelitian Anami (2018) seperti metode ceramah, cerita, mengamati lansung peristiwa dan kondisi yang ada dalam gambar, mengajak untuk merasakan kondisi yang dialami dalam gambar, metode tanya jawab denganmengajakinteraksi langsung kepada anak berkebutuhan khusus dan anak normal. Metode diskusi: dengan melibatkan siswa berkebutuhan khusus dan siswa normal dalam satu kelompok dan juga melalui keteladanandengan mencontohkan langsung dengan sikap ramah, sopan dan santun kepada anak berkebutuhan khusus, melalui pembiasaandengan 5S(Senyum, Sapa, Salim, Sopan, Santun)kepada setiap siswa. Memberikan nasihat dan motivasi: dengan menyelipkan nasihat disetiap awal dan akhir pembelajaran sebagai bentuk perhatian dan arahan dalam menghargai setiap manusia menyadarkan kembali pentingnya sikap empati. 


\section{SIMPULAN}

Tingkat perilaku bullying pada anak usia sekolah mayoritas berada dalam kategori bullying sedang sebanyak 69 siswa, 43 siswa $(62,31 \%)$ diantaranya perilaku bullying dilakuakan oleh siswa laki-laki. Jenis bullying verbal kategori sedang paling banyak ditemukan pada siswa 43 siswa laki-laki (42,16\%). Bullying fisik kategori rendah banyak dilakukan oleh 40 siswa laki-laki $(39,22 \%)$. Bullying relasional kategori sedang terbanyak dilakukan oleh 49 siswa laki-laki $(48,04 \%)$. Kurangnya empati pelaku bullying dan pencegahan yang dilakukan sekolah menyebabkan bullying terjadi disekolah.

\section{DAFTAR PUSTAKA}

Anami.(2018). Upaya Guru PAI dalam Membangun Empati Siswa Di Sekolah Inklusi SD Negeri 01 Klodran Tahun Ajaran 2018/2019. Thesis Institu Agama Islam Negeri Surakarta.

Dewi (2016). Perilaku Bullying Yang Terjadi Di Sd Negeri UnggulLampeuneurut Aceh Besar. Jurnal Ilmiah Pendidikan Guru Sekolah DasarFKIP Unsyiah Volume 1 Nomor 2,37-45Oktober 2016

Eliasa, E. I. (2017) 'Budaya Damai Mahasiswa Di Yogyakarta', Journal of Multicultural Studies in Guidance and Counseling, 1(2), pp. 175-190.

Fatmawati. (2016) Perbedaan Perilaku Bullying Ditinjau Dari Jenis Kelamin. Program studi psikologi Universitas Muhammadiyah Surakarta.

Fidrayani (2015) Pengembangan Empati Pada Anak Usia Sekolah Dasar. Seminar Psikologi \& Kemanusiaan 2015 ISBN 978-979-796-324-8

Fikrie, (2016) Peran Empati dalam Perilaku Bullying. Seminar ASEAN $2^{\text {nd }}$ Psychology \& Humanity Forum UMM 19-20 Februari 2016

Jollieffe, D \& Farrington P. (2006) Examining The Relationship Beetween Low Empathy And Bullying. Agrressive Behaviour, 32,540-550

KBBI daring. (2019). Diperoleh dari https://kbbi.kemendikbud.go.id
Kusuma, M. P. (2016) Perilaku School Bullying Pada Siswa Sekolah Dasar Negeri Delegan 2, Dinginan, Sumberharjo, Prambanan, Sleman, Yogyakarta. Universitas Negeri Yogyakarta.

Linda. (2019) Sepanjang 2018, 179 Kasus Bullying Anak Remaja Terjadi di Sleman. Diperoleh dari : Sepanjang 2018, 179 Kasus Bullying Anak Remaja Terjadi di Sleman-Tribun Jogja https://www.google.com/amp/s/jogja. tribunnews.com/amp/2019/02/20/sepnaj ang-2018-179-kasus-bullying-anakremaja-terjadi-di-sleman. Diakes pada tangga 11 Oktober 2019

Novitasari, T. (2017) 'Pola Asuh Orang Tua Abstrak', academia.edu, pp. 1-11.

Rukmantara, A. (2019) 21 Persen Anak Sekolah di DIY Masih Alami Perundungan. Diperoleh dari : rukmantara 2019 bullying - penelusuran google

https://www.google.com/amp/s/m.repub lika.co.id/amp/pmt27q383. Diakses pada tanggal 11 Oktober 2019

Sari, Y. P. and Azwar, W. (2017) 'Bullying bullying', 10(November), pp. 333-367.

Taufik (2012).Empati Pendekatan Psikologi Sosial. Jakarta: Rajawali Press.

Yusuf, S. (2011) Psikologi Perkembangan Anak dan Remaja. 12th edn. Indonesia: Rosda.

Zakiyah, E. Z., Humaedi, S. and Santoso, M. B. (2017) 'Faktor Yang Mempengaruhi Remaja Dalam Melakukan Bullying', Jurnal Penelitian \& PPM Unpad, 4, pp. 324-330. 
Jurnal Keperawatan Jiwa Volume 7 No 3 Hal 237 - 246, November 2019

FIKKes Universitas Muhammadiyah Semarang bekerjasama dengan PPNI Jawa Tengah 